Targioni-Tozzetti, are elucidated, with some corrections to the last named author.

Under the head of organs accessory to the intestinal canal, the author announces the discovery of salivary glands, and it is to an exact exposition of the anatomical and histological nature of these organs that a large portion of the article is devoted. The organs in question have been previously seen and described, but, from a want of exact topographical and histological knowledge, have been incorrectly assigned to the nervous system. The salivary glands are found to exist in the Aphidae as well as in the Coccidae, and in both families have the same general plan of structure. A pair of sack-like, more or less extensively lobed glands, placed over the mouth-parts, and flanking the subœsophageal ganglion, are traversed each by an excretory duct, arising by a varying number of finely punctured tubes, and passing forward and downward to unite with its fellow of the opposite side to form a short stem; the latter empties directly into the osophagus at its initial end.

Another organ, thought to be a second salivary gland, of somewhat different function, is found to exist in certain of the Coccidae (Aspidiotus and Chionaspis).

The Malpighian vessels are very briefly considered.

The article is illustrated by three colored plates drawn by the author.

Edward L. Mark.

\title{
Notes on Attaci.
}

Telea Polyphemus. Larva feeds upon birch, oak, elm, maple, hazel, cherry, walnut, willow, linden. I should think that the fact of its feeding upon willow might be of value to any one who intends to raise silk, for willow is easily cultivated and grows rapidly. From May 25 to July 15.

Actias Luna. Larva eats birch, oak, walnut, hop hornbeam, chestnut. I once found a small birch tree in Weston nearly stripped by Luna larvæ. I counted them carefully, and found that there were no less than forty-five. With this exception, I have never found more than five or six on one tree. Full grown larvæ vary very much in size. In the Can. Ent., vol. vi, p. 86, Mr. Gentry describes a variety of the larva in which 
the general color is "reddish brown inclining to dullness." I have raised about five hundred Lunas, and to my knowledge no larva spun its cocoon without turning dull reddish brown some time before. The moths sometimes fly to a lamp. I have never been able to attract many by exposing a female; the largest number that $I$ have attracted in one night is nine.

Callosamia Promethea. Larva eats button bush, cherry, sassafras, spice bush, apple, ash, lilac. It is a curious fact that the males fly only during the afternoon, from about three to six o'clock. They often come in large numbers to a fresh female. I never saw a female flying by day; I think they fly by night only. Cocoons may be found often in large numbers, hanging on button bush, by river banks, in winter. I have often found hundreds thus in one day.

Platysamia Cecropia. Larva feeds upon button bush, apple, wild cherry, ash, barberry, blue-berry, birch, oak, hazel, maple, elder-berry, alder, jersey tree, buck thorn. Males often come in large numbers to a fresh fernale. I have taken forty-three in one evening. Males vary very much in color. I have one of a bright orange color, which came to a female. $R$. Thaxter.

\section{BIBLIOGRAPHICAL RECORD.}

Authors and Societies are requested to forward their works to the Editor at the earliest date possible. We ask our readers to inform us of the publication especially of those works which are not generally consulted by entomologists.

B. Pickman Mann.

(Continued from page 192.)

Nos. 585 to 589 are from the Proc. Amer. Assoc. Advanc. Sci., vol. xxiv, part ii.

* 585. C. V. Rilex. The Locust Plague; How to avert it. p. 215-222.

Ravages committed by Caloptenus spretus in the Western United States, in 1873,1874 and 1875 ; natural agencies and artificial means to be employed in the destruction of the eggs and unfledged young (the winged insects being uncontrollable); importance of governmental assistance toward s the investigation and adoption of further means of prevention.

* 586. A. R. Grote. The Effect of the Glacial Epoch upon the Distribution of Insects in North America. p. 222226.

[Same as the article cited in Rec., No. 507, slightly amended.] 

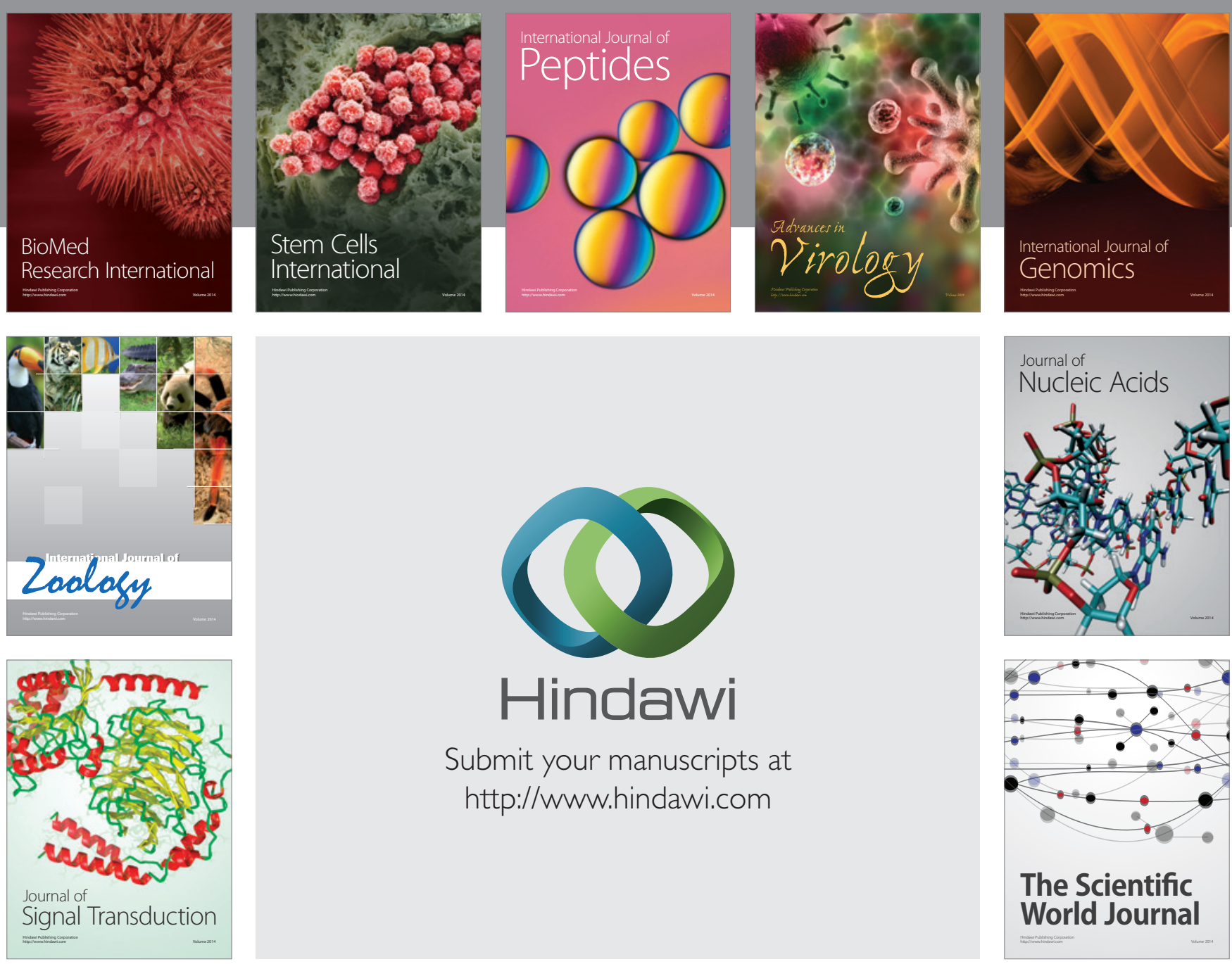

Submit your manuscripts at

http://www.hindawi.com
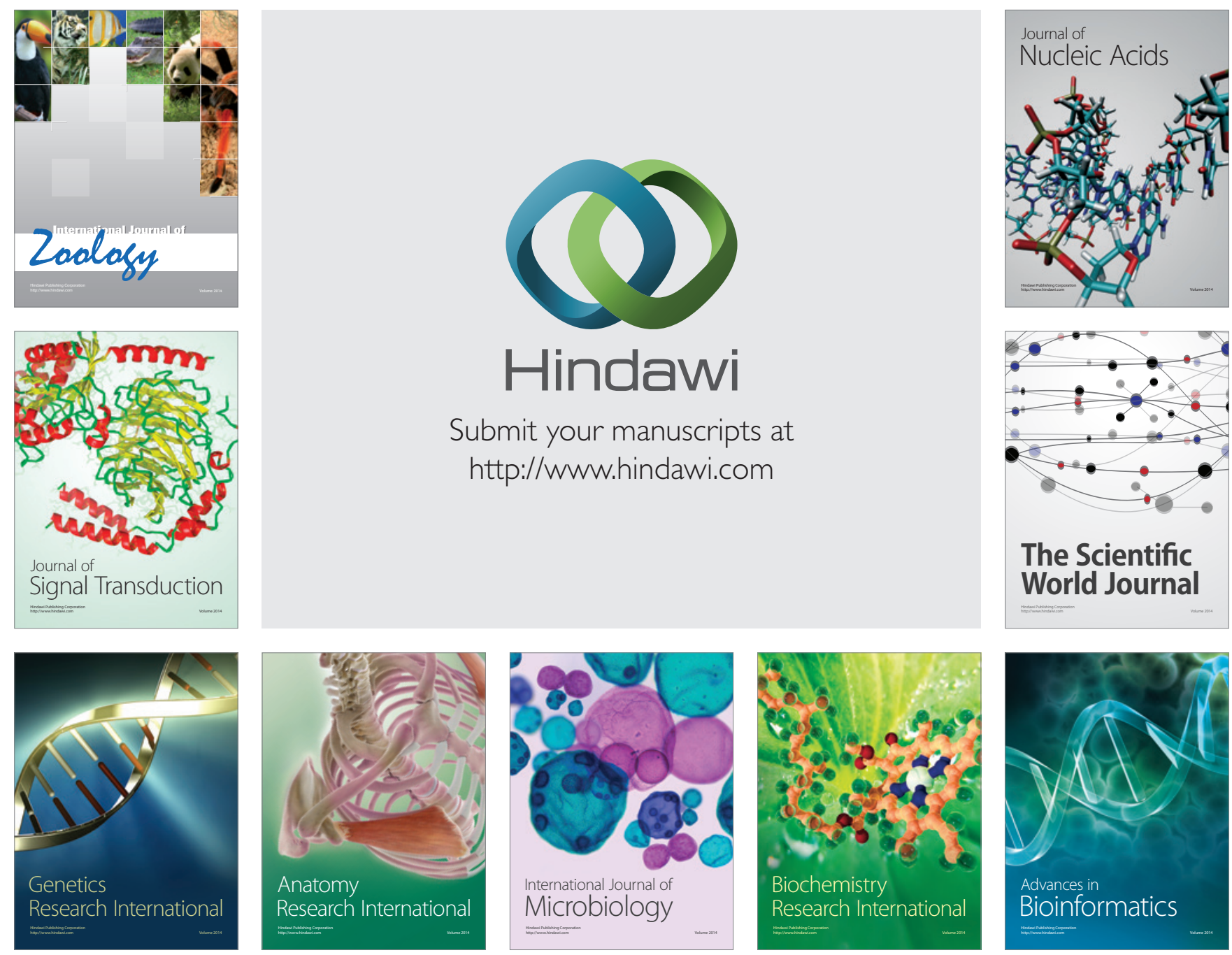

The Scientific World Journal
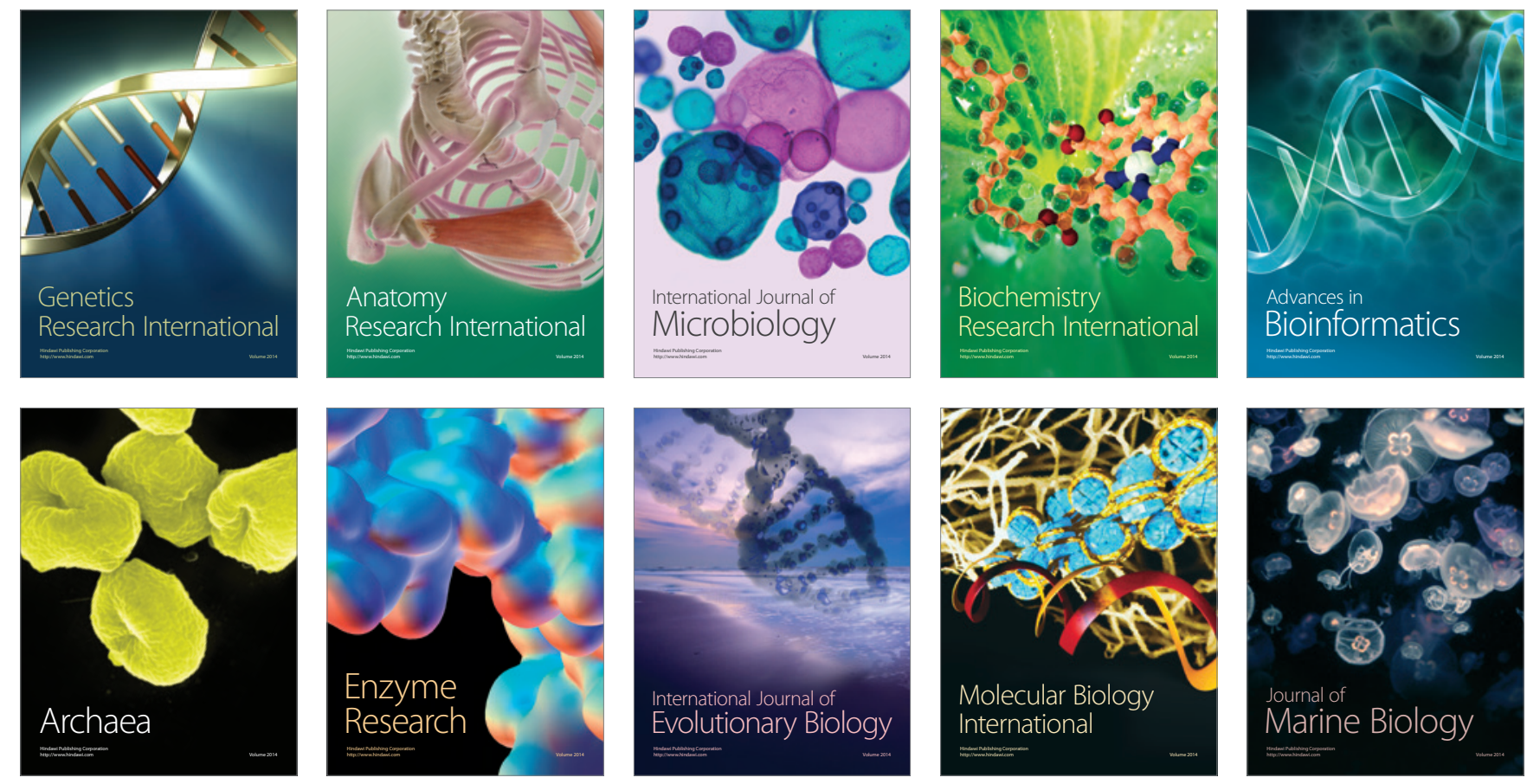